\title{
Signifikansi Pendidikan Lingkungan di Perguruan Tinggi
}

\author{
Oleh Gede H. Cahyana
}

\begin{abstract}
Environmental education in Indonesia has not been given big attention yet, formal and nonformal, by the government. A little of local governments give their interest in environmental education in local subject of curriculum, especially in elementary, junior and senior high school. There are some differences in the name of the subject in universities. The subject of environmental knowledge (not education) has been studied since 1970's. If so, is the university need the course of that if the sudents have get the local subject? Environmental education is the long life education, must be given from elementary or kindergarten to university and so after the student become apart of population in community, practically and/or theroterically.
\end{abstract}

\section{Keywords: environmental, knowledge, education, enviro intelligence - quotient.}

\section{Latar Belakang}

Dapat dipastikan, semua orang tahu lingkungan. Tak seorang manusia pun yang tidak tahu perihal lingkungan. Kaum Badui di Kabupaten Lebak Provinsi Banten pasti berteman dengan lingkungan. Komunitas Trunyan di sekitar Danau Batur dan warga Tenganan di Bali juga berkawan dengan lingkungan. Suku Anak Dalam di pedalaman Jambi pun bagian dari lingkungan. Suku Tengger di Bromo pasti mengenali lingkungannya. Begitu juga Dayak, Batak, Sasak, dan suku-suku di Papua, Sulawesi, dan kelompok masyarakat lainnya adalah bagian dari lingkungan, termasuk manusia yang tinggal di perkotaan. Singkatnya, manusia tanpa kecuali, dikitari oleh lingkungan.

Sejak lahir sampai maut menjemputnya, manusia akrab dan bermain dengan lingkungan. Setelah dimakamkan, jasadnya bersatu dengan lingkungan kemudian memberikan kehidupan berupa nutrisi kepada mikroba, rerumputan dan pohon di sekitarnya. Sebelum malaikat Izrail melaksanakan tugasnya, yakni selama mengisi hidupnya di dunia, manusia banyak belajar tentang lingkungan, termasuk semasa menjadi murid di pesantren, sekolah atau madrasah. Pelajaran kimia, biologi, fisika, dan geografi banyak mengetengahkan lingkungan dan masalahnya. Kalau demikian, mengapa murid yang sudah belajar biologi di pesantren, sekolah atau madrasah diwajibkan lagi mengambil mata kuliah lingkungan ketika berstatus mahasiswa? Lantas, mengapa namanya Pendidikan Lingkungan (environmental education) bukan Pengetahuan Lingkungan (environmental knowledge) seperti yang digunakan di perguruan tinggi lain dan sudah berlangsung sejak dekade 1970-an?

\section{Aspek Sejarah}

Masalah lingkungan, misalnya pencemaran (polusi, pollution) air, tanah, dan udara secara masif (massive), besar-besaran terjadi di semua daerah di Indonesia, di desa maupun kota tanpa kecuali. Sebabnya berbagai macam, satu di antaranya adalah 
pengusaha yang hanya mengeksploitasi sumber daya alam dan abai pada kelestariannya. Mereka tak peduli pada bencana lingkungan yang mengintai anakcucunya pada masa depan. Ketika dibawa ke meja hijau hanya sedikit di antara mereka yang berhasil dibui, selebihnya bebas melenggang ke luar penjara. Yang berhasil dipenjarakan pun hanya sekadarnya, singkat waktunya sehingga tidak menghasilkan efek jera. Perusakan lingkungan pun terjadi lagi, bahkan lebih parah daripada sebelumnya. Itu sebabnya, perangkat peradilan (jaksa, hakim, polisi) wajib memahami seluk-beluk masalah lingkungan sehingga mampu maksimal memenjarakan pengacau lingkungan.

Semua ragam kasus pencemaran lingkungan, baik yang disebabkan oleh pabrik maupun domestik (rumah tangga), menjadi cermin betapa rendah mutu pengelolaan lingkungan kita yang diawali oleh kegagalan pendidikan lingkungan atau baru sebatas pengetahuan saja, belum menjadi karakter harian (afektif) dan perilakunya (psikomotorik). Apatah lagi kalau tak diberikan pendidikan lingkungan, dipastikan sarjana yang kian banyak jumlahnya akan buta-tuli soal lingkungan. Mereka tuna lingkungan. Sains dan teknologi hanyalah alat bantu yang terus berkembang hasil olah pikir, kontemplasi dan riset saintis-teknolog. Bisa dikatakan, kerusakan lingkungan bukan karena sains dan teknologi melainkan karena etika, moral dan lifestyle manusia. Banyak contoh yang dapat diketengahkan perihal peran moral dan gaya hidup sebagai sumber bencana. Dapatlah dipahami pendapat yang mengatakan bahwa tidak ada bencana alam. Yang ada hanyalah bencana akibat ulah manusia yang tidak arif terhadap alam (environmental wisdom), tidak bersahabat dengan lingkungan (environmental friendly) dan hanya berpikir anthropocentris bukan envirocentris.

Faktanya demikian. Kebanyakan manusia enggan memedulikan lingkungan. Sebagai contoh, pencemaran air, tanah, dan udara selalu terjadi dan makin parah dari waktu ke waktu. Begitu juga banjir akibat pembabatan hutan, buang sampah ke selokan dan sungai seperti yang selalu menimpa ibukota Jakarta. Bahkan Benyamin S, seorang aktor asli Betawi, lewat lagunya sudah memperingatkan penduduk dan pejabat di Jakarta bahwa daerahnya rawan banjir. Sudah sejak 1970-an Jakarta dilanda banjir dan terjadi sampai sekarang, terutama ketika musim hujan. Tidak hujan pun sering juga banjir karena mendapat kiriman air bah dari dataran tinggi di Cianjur dan Bogor. Tidakkah kalangan pintar di Jakarta itu belajar dari pengalaman sehingga kecerdasan lingkungan (Enviro Intelligence) atau Enviro Quotient (EnQ) mereka menjadi lebih baik, lebih tinggi?

Satu hal yang dilupakan pejabat di Jakarta ialah mengelola lingkungan secara bersahabat. Mereka tidak optimal mengelola EnQ tetapi hanya berbekal kecerdasan otak (Intelligent Quotient) tetapi miskin kecerdasan akhlak (Spiritual Intelligence). Padahal sejak 1970-an wanti-wanti itu sudah dirilis oleh Prof. Dr. Sumitro Djojohadikusumo. Begawan ekonomi penulis Science, Resources, and Development ini pada tahun 1977 telah memperingatkan pemerintah bahwa akan terjadi booming 
dan blooming teknologi yang dapat menjadi bumerang bagi manusia kalau tidak arif menyikapinya. Mantan menteri ini menyatakan bahwa harus ada teknologi yang protektif (protective technology) atas lingkungan. Idenya itu dipublikasikan sebelum rezim Orde Baru merilis Kementerian Negara Kependudukan dan Lingkungan Hidup (Menneg KLH) pada tahun 1978.

Teknologi protektif pada masa sekarang justru menjadi poin terpenting karena berkaitan langsung dengan kelestarian fungsi lingkungan, keterkaitan antara manusia dan alamnya. Semua manusia tanpa kecuali, kaya miskin, tua muda, dapat menjadi agen perusak atau pemberdaya lingkungan. Sudah pula terbukti, deretan gelar akademik dan kepangkatan seseorang, juga hartanya, tidak berkorelasi linier dengan pemahamannya atas persoalan lingkungan. Banyak orang pintar yang berjabatan dan berpangkat justru menjadi pelaku masif balak-liar (illegal logging). Nihil rasa memilikinya (sense of belonging). Mereka tidak merasa menjadi pemangku (stakeholders) fungsi lingkungan lantaran tidak maksimal pemahamannya atas fungsi lingkungan. Atau, mereka memang belum tahu peran penting kelestarian fungsi lingkungan sehingga berpendapat bahwa lingkungan boleh dieksploitasi seenak perutnya.

Namun kalau berpikir positif, perilaku di atas masih bisa diubah dan belum terlambat karena bisa belajar Pendidikan Lingkungan secara informal. Sebab, ciri khas pendidikan (tarbiyah, education) ialah seumur hidup, sampai akhir hayat. Di mana pun dan kapan pun, manusia perlu pendidikan, baik yang berkaitan dengan jasmani maupun ruhani. Dua jenis pendidikan ini sesungguhnya bersatu dalam perbedaan, seolah-olah bayi kembar yang berasal dari satu sel telur (ovum) sehingga sekilas tak dapat dibedakan. Pendidikan memasukkan dua kategori besar, yaitu sains (science) dan teknologi (technology). Keduanya saling dukung untuk menghasilkan produk berupa barang dan jasa yang dapat melancarkan kegiatan manusia. Produk inilah yang dapat menghasilkan nilai positif bagi lingkungan sekaligus menimbulkan dampak negatif berupa masalah lingkungan. Masalah lingkungan yang diakibatkan oleh perkembangan sains dan teknologi dapat berujung pada derita manusia. Tetapi bisa juga berujung pada kebahagiaan manusia lantaran sains, teknologi, lingkungan merupakan segitiga sama sisi yang masing-masing berperan dalam kehidupan manusia. Terminologi yang digunakan ialah Trilogi Pendidikan.

Di bagian awal artikel ini ada pertanyaan, mengapa perlu diadakan Pendidikan Lingkungan di perguruan tinggi? Bukankah sudah ada pelajaran serupa di SD, SMP, SMA, dan pesantren (islamic (classical) boarding school)? Betul..., sudah ada pelajaran yang erat kaitannya dengan lingkungan dan memiliki variasi nama yang khas. Namun tidak semua pesantren, madrasah, SD, SMP, SMA, SMK baik yang negeri maupun swasta sudah menyediakan pelajaran lingkungan secara formal. Mayoritas siswa belum diberikan pelajaran lingkungan secara khusus, bukan menjadi bagian kecil dalam sebuah pelajaran, misalnya pelajaran biologi. Artinya, kedudukan mata pelajaran atau mata kuliah Pendidikan Lingkungan selayaknya setara dengan 
mata pelajaran atau mata kuliah yang lain. Sekadar contoh, Di ITB mata kuliah ini dinamai Pengetahuan Lingkungan dan diberikan kepada mahasiswa Tahun Pertama Bersama (TPB) yang berlangsung sejak 1975 sampai sekarang.

Secara ekopolitis, Pendidikan Lingkungan kali pertama dikenalkan pada konferensi International Union for Concervation of Nature and Natural Resourses atau Perserikatan Internasional untuk Konservasi Alam dan Sumber Daya Alam pada 1971. Konferensi yang berlangsung pada 15 s.d 18 Desember 1971 di Gottlieb Duttweiler Institute di Ruschlikon, Zurich berhasil merumuskan definisi Pendidikan Lingkungan sebagai berikut: Environmental education is the process of recognizing values and clarifying concepts in order to develop the skills and attitude that are necessary to understand and appreciate the interrelations among man, his culture, and his biophysical surrounding. Environmental education also entails practice in decision-making, and the self-formulation of code of behaviour about the issues concerning environmental quality. Definisi tersebut ditulis di dalam "Unesco, Nature and Resources, Vol. VIII, No. 3, July - September 1971, Paris (Sumaatmadja, 1991).

Namun historisnya, jauh sebelum politisi dunia mengangkat isu lingkungan ke pentas politik, sudah ada sejumlah karya tulis di tataran ilmiah populer. Rachel Carson misalnya, seorang ibu rumah tangga, setelah dari hari ke hari menyaksikan lingkungan tempat tinggalnya, ia mulai merasa kehilangan nuansa ekologinya. Tiada lagi burung berkicau, sapi dan domba banyak yang mati. Ada yang salah, pikir Carson waktu itu. Lalu terbitlah bukunya dengan judul The Silent Spring (Musim Bunga Yang Sunyi) pada 1962 yang kemudian menjadi best seller dan ikut membentuk pola pikir setiap "politisi hijau" di Amerika Serikat. Buku fenomenal itu lantas berubah seolah-olah menjadi "textbook" di tataran akademisi, pebisnis dan politisi, selain dibaca oleh masyarakat awam sampai sekarang.

Pada awal dekade berikutnya di tingkat dunia peran politisi hijau semakin besar. Stockholm, sebuah kota di Swedia mencatat sejarah dan pasti selalu tersirat di benak pencinta lingkungan. Pada 5 Juni 1972 di kota itu berlangsung konferensi PBB tentang lingkungan hidup (UN Conference on the Human Environment). Kota Stockholm dipilih karena paparan masalah lingkungan pertama kali dicetuskan oleh wakil dari Swedia ketika sidang PBB pada 28 Mei 1968. Hasilnya adalah Deklarasi Stockholm yang lantas dijadikan acuan oleh negara peserta untuk peduli lingkungan, advokasi lingkungan dan membentuk kementerian lingkungan. Di Indonesia dinamai Kementerian Negara Kependudukan dan Lingkungan Hidup (Menneg KLH) yang sekarang sudah bermetamorfosis menjadi Kementerian Negara Lingkungan Hidup.

Yang juga dapat dijadikan tonggak awal perkembangan Pendidikan Lingkungan ialah kasus pencemaran lingkungan terbesar di Jepang, yaitu Minamata yang terjadi sporadis antara tahun 1950 - 1970. Kasus besar ini berkaitan dengan limbah metilmerkuri yang mencemari ikan dan kerang laut yang merupakan makanan seharihari orang Jepang. Akibatnya, muncullah visi baru tentang lingkungan yang dengan 
cepat mencuat di tataran elite politiknya. Kemudian warganya yang ketakutan dan merasa terancam hidupnya menyerukan agar pejabat pemerintahan dan politisi peduli pada lingkungan. Selanjutnya politisi di Diet Jepang intensif menyusun rancangan undang-undang yang akhirnya menghasilkan 14 buah undang-undang. Sebab itulah di Jepang muncul sebutan Pollution Diet pada dekade 1970-an.

Bagaimana di Indonesia? Dalam versi pemerhati lingkungan sejak dulu sampai sekarang (2009) nyaris tidak ada politisi hijau di Indonesia. Padahal spirit ekologi di dalam konstitusi kita, yakni pasal sosioekologi (pasal 33 UUD 1945) jelas-jelas mengakomodasi potensi lingkungan yang dikedepankan oleh the founding fathers. Meskipun pada masa itu mereka tidak sempat "berteriak" perihal lestarikan fungsi lingkungan, merekalah politisi hijau yang sesungguhnya, yang peduli pada ruang hidupnya. Politisi dari beragam daerah itu mewakili tradisi konservasi ekologi daerahnya. Hal ini masih melekat hingga kini di kalangan masyarakat meski telah terkontaminasi oleh kepentingan politik dan ekonomi pemerintah (pusat, daerah). Tetapi eksistensinya tetap terjaga semacam kearifan masyarakat tradisional. Artinya, politisi dan birokrat kita hendaklah belajar kearifan ekologi kepada kaum yang dianggap "tak terdidik" yang tinggal jauh di pelosok.

Tradisi ujung ladang masyarakat Melayu di Sumetera Utara misalnya, selalu berwawasan lingkungan kalau akan membuka hutan. Meskipun menebang pohon dan membabatnya, selalu saja ada vegetasi pelindung yang tersisa. Pola seperti ini membantu menahan tanah agar tidak erosi atau merusak tanaman. Suku Dayak di Kalimantan punya tradisi Nyaang. Mereka biasa membuat lajur isolasi pada ladang atau ketika membabat hutan untuk melokalisir kebakaran. Begitu pun awig-awig orang Bali yang melarang menebang pohon (bunut atau beringin). Kemudian, tradisi sasi di Saparua Maluku berlaku di darat atau di laut atas komoditi yang haram dieksploitasi untuk waktu terbatas. Semuanya adalah kearifan tradisional masyarakat yang awam dengan konsep atau teknologi terbaru yang diagung-agungkan orang kota yang justru sering merusak lingkungan.

Tidakkah politisi dan birokrat Indonesia belajar dari kearifan tradisional itu? Apakah kepedulian politisi-birokrat atas lingkungan memang kalah oleh para "tradisionalis" itu? Adakah politisi-birokrat yang tak sekedar peduli lingkungan dalam retorika politiknya belaka, terutama menjelang pemilu? Adakah partai politik yang tak sekadar proforma membuat biro atau divisi lingkungan? Adakah anggota dewan yang berpolemik dengan birokrat, pemerintah menyangkut masalah pelestarian fungsi lingkungan? Yang terjadi malah sejumlah politisi, baik di pusat maupun di daerah, terlibat dan melindungi pembalak liar kayu hutan dan berada di balik alih fungsi hutan dan lahan di daerah-daerah di Indonesia. Hasilnya, banyaklah birokrat, pejabat dan anggota DPR yang ditangkap oleh KPK, meskipun pada saat berikutnya, ketua KPK (Komisi Pemberantasan Korupsi) berinisial AA juga ditangkap dengan tuduhan terlibat pembunuhan seorang direktur perusahaan. 
Banyak lagi contoh seperti itu diberitakan di koran-koran lokal dan nasional. Tak hanya di bidang "kebijakan" yang tidak bijak dan manipulatif, banyak juga program yang usianya hanya seumur jagung. Berikut ini ada beberapa yang pernah menjadi isu nasional. Dulu ada program Segar Jakartaku dan Hari Tanpa Kendaraan Bermotor. Juga ada Langit Biru. Ada satu lagi, Prokasih: Program Kali Bersih. Dalam lingkup Jawa Barat ada Masyarakat Cinta Citarum. Dari sekian banyak itu, tiada satu pun yang signifikan berhasil. Jakarta kian gerah, kendaraan bermotor makin banyak, langit terus kelabu, dan air Citarum menghitam. Banjir sudah tak terhitung lagi. Program lokal juga ada seperti Gerakan Cikapundung Bersih di Kota Bandung yang akhirnya sekadar seremonial belaka, kehabisan tenaga di tengah jalan (Cahyana, G. H, 2004).

Kalau begitu adanya, adakah politisi-birokrat yang berorientasi ekologi saat ini? Patut diakui, kementerian yang mengurusi masalah lingkungan mulai 1978 sampai sekarang masih ada. Di antara produk undang-undangnya adalah UU No. 4 tahun 1982 tentang Ketentuan Pokok Pengelolaan Lingkungan Hidup yang didukung oleh sejumlah peraturan pemerintah dan keputusan menteri untuk tindak lanjutnya. Karena perlu perbaikan, telah pula dikeluarkan UU No. 23 tahun 1997 tentang Pengelolaan Lingkungan Hidup. Kemudian disahkan juga UU No. 7 tahun 2004 tentang Sumber Daya Air. Lantas, kapankah undang-undang tentang Pendidikan Lingkungan dirancang? Undang-undang ini diperlukan untuk membangkitkan spirit mahasiswa, murid, santri sekaligus memberikan landasan yang kuat dalam hukum positif kita.

Apakah spirit Pendidikan Lingkungan? Menurut IUC seperti ditulis di atas, Pendidikan Lingkungan berkaitan dengan penanaman nilai-nilai (values) hubungan antara manusia dan lingkungannya, mengembangkan kemampuan dan perilaku yang diperlukan untuk memahami hubungan antara manusia, budaya, dan lingkungan biofisikanya (termasuk kimia, yakni biofisikokimia, tambahan dari penulis). Pendidikan Lingkungan juga melatih manusia khususnya murid, santri, mahasiswa dalam upaya pengambilan keputusan yang bertanggung jawab atas isu lingkungan kemudian menerapkannya dalam diri peserta didik dan pendidik (selanjutnya istilah peserta didik diakronimkan menjadi pedidik). Semua itu dilakukan demi mempertahankan (melestarikan) kualitas dan fungsi lingkungan.

Lantas fakta berkata, Pendidikan Lingkungan belum optimal hasilnya. Ada berbagai sebab, mulai dari lingkup materi pelajaran, metode pembelajaran, kemampuan guru, dan perilaku santri, murid, mahasiswa sebagai pedidik. Sebagai contoh, mari dikaji mata pelajaran lingkungan di Kota Bandung, Jawa Barat. Sejak 2008 muatan lokal Pendidikan Lingkungan Hidup (Mulok PLH) dilaksanakan di sekolah-sekolah di Kota Bandung. Tujuan pelajaran ini, menurut Peraturan Walikota No. 031/2007 tentang Muatan Lokal Pendidikan Lingkungan Hidup, adalah mendukung upaya perbaikan kualitas lingkungan Kota Bandung agar menjadi tertib, bersih, dan indah. Materi pokok yang diharapkan diserap dan diterapkan murid (juga gurunya) meliputi 
konsep dasar lingkungan hidup, K3 (Ketertiban, Kebersihan, Keindahan), P4LH (Pembibitan, Penanaman, Pemeliharaan, dan Pengawasan Lingkungan Hidup), dan penerapan Iptek (ilmu pengetahuan dan teknologi) dalam mengelola lingkungan.

Bagaimana pelaksanaannya di sekolah? Dari hasil survei penulis dan tanya jawab dengan guru dan murid-muridnya dapat disimpulkan bahwa pelaksanaan PLH belum tepat sasarannya. Tidak semua sekolah atau tidak semua satuan pendidikan memberlakukan muatan lokal ini. Ada sekolah yang sudah mengajarkan PLH tetapi terbatas sebagai sisipan dalam pelajaran biologi, sekadar tambahan dan tidak menjadi pelajaran inti. Karena bentuknya sisipan maka tidak mendapat perhatian mendalam dari siswa maupun gurunya. Apalagi ada kata "lokal" yang ditempelkan pada pelajaran itu. Kata tersebut menyebabkan murid dan gurunya menganggap PLH tidaklah penting atau dianaktirikan sehingga seperti ada tapi tiada, sekadar aksesoris. Bahkan ada sekolah yang menyatakan di dalam kurikulumnya sebagai pelajaran yang bersatu dengan biologi dan ditulis di dalam kurung. Tak salah memang, sebab lingkungan ini demikian luas dan bisa dimasuki dari banyak sudut pelajaran seperti biologi, kimia, IPA, geografi, dll. Tetapi sayang, tidak ada guru khusus yang mengampu pelajaran ini yang memberikan pengenalan konsep dasar sains dan teknologi lingkungan.

Atas dasar fakta tersebut bisa disimpulkan bahwa muatan lokal PLH hanya ditempatkan sebagai pelajaran proforma dan tidak diseriusi. Oleh sebab itu, pemerintah pusat dan daerah diharapkan mereposisi mulok ini termasuk menyusun rancangan undang-undang Pendidikan Lingkungan agar menempati posisinya sesuai dengan harapan dan agar dapat memberikan ilmu, wawasan, dan pengalaman kepada guru, dosen dalam memandang lingkungan dari segi rekayasa (engineering) sekaligus mengubah stereotipe guru, dosen, santri, murid dan mahasiswa dalam memandang lingkungan. Konsepnya dapat diadopsi dari Trilogi Pendidikan: sains (science), teknologi (technology), dan lingkungan (environment).

\section{Opsi Solusi}

Mari kembali ke pertanyaan tentang kata "pendidikan" dan "pengetahuan". Kata pendidikan bermakna memberikan pembelajaran, yaitu proses transfer ilmu dan teknologi, sekaligus memasukkan nilai-nilai moral dalam interaksi manusia dengan lingkungannya. Adapun pengetahuan atau knowledge terbatas pada "tahu" (know) yang nilainya di bawah kata didik. Sasaran pendidikan adalah aspek kognitif, afektif dan psikomotorik yang mengandung makna tahu kemudian membentuk sikap mental (afektif) yang lantas diterapkan berupa keterampilan (psikomotorik) dalam hidup sehari-hari lewat kemampuan di bidang (jurusan, program studi) masing-masing. Wujudnya ialah pelibatan sarjana dari semua disiplin ilmu dan teknologi (sainstek) dalam upaya melestarikan fungsi lingkungan.

Telaah sasaran pendidikan di atas berujung pada peningkatan peran pemerintah pusat-daerah dalam memfasilitasi guru, ustadz, dosen sehingga dapat efektif 
mengantarkan murid, santri, dan mahasiswanya memperoleh pengalaman positif yang mendukung upaya pelestarian fungsi lingkungan. Guru, ustadz, dosen hendaklah diberikan pelatihan (training), seminar, atau bentuk lainnya tentang Pendidikan Lingkungan dengan memberikan fokus materi berupa masalah lingkungan seperti krisis air minum, air limbah, sampah, udara, kesehatan lingkungan, kebisingan, dll yang terangkum dalam akronim watsanen atau water, sanitation, environment tanpa melupakan cabang ilmu lingkungan, yakni ekologi, "anak" mata pelajaran biologi.

Untuk implementasinya pemerintah pusat-daerah dapat menyelenggarakan Pelatihan Pendidikan Lingkungan (Latdikling) dalam upaya mewujudkan sekolah dan kampus yang bersahabat dengan lingkungan (enviroschool) di seluruh Indonesia. Titik berat Pendidikan Lingkungan haruslah pada aspek afektif dan psikomotorik sehingga murid, santri, dan mahasiswa tak hanya memiliki ilmu (kognitif) tetapi juga mampu mengubah perilakunya. Mereka harus melihat bagaimana proses pencemaran air dan dampaknya bagi kesehatan. Ketika melihat sampah yang ada dalam benaknya ialah sumber daya penghasil uang. Air limbah pun dijadikan potensi pupuk buatan atau didaur ulang menjadi air minum. Pendeknya, Pendidikan Lingkungan harus mampu mendekatkan guru dan muridnya, dosen dan mahasiswanya kepada lingkungan dan menjadi bagian dari solusi. Namun harus diingat, materinya hendaklah dibatasi agar tidak meluas menjadi persoalan biologi sehingga mengaburkan masalah lingkungan yang erat dengan kehidupan sehari-hari.

Kalau hasil Pendidikan Lingkungan di pesantren, madrasah, SD, SMP, SMA belum juga optimal, maka murid yang kemudian berstatus sebagai mahasiswa di perguruan tinggi negeri/swasta hendaklah diberikan lagi mata kuliah Pendidikan Lingkungan. Hakikatnya, seperti sifat pendidikan yang dimulai dari buaian hingga dimasukkan ke liang lahat, Pendidikan Lingkungan pun demikian. Pendidikan Lingkungan ini berlangsung selamanya. Mahasiswa selayaknya didekatkan terus pada lingkungannya lewat jalur formal berupa pendidikan (perkuliahan) agar dekat dengan lingkungan. Dekat bukanlah fisiknya belaka melainkan juga spiritnya dengan cara mencintai lingkungan seperti mencintai dirinya. Itu sebabnya, mahasiswa khususnya jenjang strata satu (S1) wajib dikenalkan pada mata kuliah Pendidikan Lingkungan demi menggugah rasa memiliki atas lingkungannya.

Rasa cinta lingkungan ini dirangsang dengan stimulan tiga pilar yang telah disebut di atas, yaitu Trilogi Pendidikan. Di dalam trilogi inilah manusia tinggal (live) dan merawat kehidupannya. Mahasiswa sebagai bagian dari kelompok masyarakat yang terdidik perlu memahami lingkungannya. Manusia (mahasiswa) pasti memerlukan ilmu lingkungan. Sebab, bicara lingkungan sebetulnya bicara tentang kehidupan manusia. Manusia hidup di dalam lingkungan dan berinteraksi dengan lingkungan. Manusia perlu air, perlu udara, perlu ruang hidup yang semuanya adalah komponen lingkungan. Manusia juga mengeluarkan limbah, baik padat, cair, maupun gas dan limbah ini pun masuk lagi ke lingkungannya dan digunakan lagi oleh manusia. 
Artinya, langsung tak langsung, manusia mempengaruhi lingkungan dan juga pasti dipengaruhi oleh lingkungannya.

Kepedulian manusia pada lingkungan menjadi konsekuensi logis interaksi manusia dan lingkungan. Mau tak mau, suka tak suka manusia harus akrab dengan lingkungan. Sebelum mencapai taraf akrab itu manusia harus tahu dan paham dulu tugasnya terhadap lingkungan. Jangan sampai manusia tidak tahu apa yang mesti dilakukannya terhadap lingkungan dan peran apa yang diembannya sebagai makhluk berakal yang mampu mempengaruhi kualitas lingkungan. Sebab, manusialah yang mampu merusak dan memperbaiki mutu lingkungan. Tetapi sayang, tak semua orang memahami lingkungan. Jangankan paham, tahu saja pun tidak. Makin besar lagi keburukannya ketika kaum terdidik atau kalangan sekolah tidak tahu dan tidak paham tentang tugasnya sebagai pelestari fungsi lingkungan. Bahkan apa itu lingkungan pun masih banyak yang belum tahu. Setiap bicara lingkungan selalu saja pikirannya mengarah kepada pohon, udara, dan air. Tidak salah, memang! Tetapi masalah lingkungan jauh lebih kompleks daripada sekadar pohon, air, dan udara.

Lantas, adakah alat yang dapat digunakan untuk meluaskan peran dan paham manusia (baca: murid, mahasiswa) terhadap pelestarian fungsi lingkungan? Secara kelembagaan, pemerintah memang memiliki lembaga dan/atau badan yang mengurusi bidang lingkungan. Tak perlu disebut di sini apa saja lembaga dan/atau badan itu. Tetapi faktanya lembaga dan/atau badan ini belum mampu berfungsi optimal untuk meluaskan pemahaman masyarakat (juga murid dan mahasiswa) atas lingkungan. Malah cenderung lembaga/badan ini bertugas sendiri-sendiri, terlepas dari perannya sebagai agen pemberdaya masyarakat dalam hal lingkungan. Segala yang dibuat menjadi sekadar proforma demi orientasi politik sesaat.

Bagaimana hasil Pendidikan Lingkungan di perguruan tinggi? Tentu saja tidak bisa segera tampak, tak bisa instan. Pendidikan apapun, khususnya bidang lingkungan bukanlah seperti main sulap atau semacam kun fayakun. Hasilnya baru akan tampak setelah sekian tahun, setelah murid dan mahasiswa, juga guru dan dosennya berupaya menerapkannya dalam keseharian. Pendidikan Lingkungan membutuhkan proses, perlu waktu panjang untuk pembentukan perilaku, yaitu perilaku manusia pencinta lingkungan, manusia yang peduli pada pembangunan yang berkawan lingkungan. Istilah formalnya, pembangunan berwawasan lingkungan (sustainable development).

Demikianlah bagian awal yang dijadikan pintu masuk (brainstorming) tentang kondisi lingkungan dan perilaku (akhlak) manusia terhadap lingkungan. Aspek sejarah ringkas tentang perkembangan kepedulian atau ketakpedulian manusia atas lingkungan lalu diikuti oleh opsi yang dapat diambil untuk menyelesaikan (bukan memecahkan) masalah lingkungan diharapkan dapat mengantarkan mahasiswa (dan siswa) ke dalam mata kuliah (pelajaran) Pendidikan Lingkungan. 


\section{Kompilasi}

Spirit tulisan ini adalah mengajak mahasiswa, siswa, guru, dosen dan siapa saja yang ingin mempelajari seluk-beluk lingkungan agar tidak hanya melihatnya dari "kacamata" sains (ilmu murni) tetapi juga teknologi (terapan), termasuk teknologi tepat guna yang sederhana (appropriate technology) sehingga dapat diterapkan oleh mahasiswa yang Kuliah Kerja Nyata (KKN), Kuliah Lapangan (Kulap) atau apapun namanya, baik di desa maupun di kota. Mahasiswa diharapkan berhasil meningkatkan ranah afektif dan psikomotoriknya terhadap lingkungan setelah lulus mata kuliah Pendidikan Lingkungan, tidak hanya berhasil di ranah kognitif (sekadar memiliki ilmu atau pengetahuan lingkungan).

Oleh sebab itu, mata kuliah Pendidikan Lingkungan memiliki tujuan antara lain: (1) mahasiswa (peserta didik atau pedidik) dapat memahami bahwa manusia dan lingkungan bersifat saling mempengaruhi. Manusia bisa menjadi subjek sekaligus objek penderita ketika berhubungan dengan lingkungan. Namun kuncinya tetap di tangan manusia sebagai makhluk yang berakal, berpikir dalam pengembangan sains dan teknologi; (2) mahasiswa diharapkan mampu menganalisis masalah lingkungan yang terjadi dalam lingkup lokal (ini minimalnya), nasional, dan global serta mampu memberikan opsi solusi, minimal di dalam tataran teoretis dengan memberikan pendapat, pandangan atas masalah lingkungan tersebut. Lebih bagus lagi adalah mampu memaparkan masalah lingkungan dan memberikan opsi solusinya secara tertulis, baik dipublikasikan di media massa maupun disebarkan lewat forum informal; (3) mahasiswa mampu memantau, mengelola, memanfaatkan, kemudian mengembangkan materi dalam sainstek lingkungan untuk kehidupan manusia, hewan dan tumbuhan agar sitiran Allah dalam Surat Ar Ruum ayat 41 (telah tampak kerusakan (lingkungan) di darat dan laut karena ulah manusia) dapat dikurangi.

Siapa sasaran Pendidikan Lingkungan? Sudah jelas, sasaran Pendidikan Lingkungan adalah manusia, semua orang. Hanya saja, bisa mulai dari mahasiswa di semua program studi, jurusan di semua fakultas dengan latar belakang IPA maupun IPS. Apalagi alamiahnya Pendidikan Lingkungan bersifat universal, berlaku untuk semua orang. Dalam pelaksanaannya tentu saja dapat diperluas agar tidak hanya mahasiswa yang memperoleh ilmu lingkungan tetapi juga masyarakat umum. Oleh sebab itu, Pendidikan Lingkungan hendaklah diberikan juga kepada murid sekolah (santri, TK, SD, SMP, SMA, SMK, madrasah), orang tua yang belum pernah sekolah/kuliah, pejabat pemerintahan (pusat, daerah), pengusaha terutama yang usahanya langsung bersentuhan dengan sumber daya alam seperti hutan, tambang, air, laut, perkebunan, tekstil, industri makanan dan minuman yang sarat pencemar. Tokoh masyarakat dan tetua adat juga perlu diberikan Pendidikan Lingkungan, bahkan mereka bisa berperan kunci dalam upaya memberikan pemahaman, pengertian tentang pentingnya peduli lingkungan.

Tentu saja materi pembelajarannya harus disesuaikan dengan pedidiknya (audience). Materi ini pun dapat dimodifikasi agar dapat disampaikan kepada murid di sekolah 
menengah atau yang lebih rendah, atau diberikan kepada masyarakat umum. Agar mencapai tujuan yang diharapkan, Pendidikan Lingkungan hendaklah dilaksanakan dengan pendekatan dan metode yang nyaman bagi pedidik dan mudah dilaksanakan oleh pendidik. Pendekatan pembelajaran mengarah pada pedidik secara individual, orang per orang dan secara komunal seperti organisasi massa maupun sekolah dan perguruan tinggi. Materinya berbeda-beda, disesuaikan dengan tempat, waktu, situasi, kondisi pedidik, fleksibel atau luwes dalam pelaksanaannya.

Untuk mencapai tujuan tersebut, minimal ada tujuh metode yang dapat ditempuh dan dilaksanakan berkesinambungan, berulang-ulang karena sifat pikiran manusia yang sering lupa (diadaptasi, diubah, dan ditambah seperlunya dari Sumaatmadja, 1991).

1. Kuliah, klasikal. Metode ini dikenakan kepada mahasiswa (juga murid), diadakan secara formal di kampus (sekolah). Pedidik berkewajiban (rela atau terpaksa) belajar dan diuji (evaluasi) pada akhir semester kemudian diberikan nilai lulus atau gagal.

2. Keteladanan. Metode ini dapat diterapkan untuk semua orang di segala tempat. Kyai, ustadz memberikan keteladanan kepada santrinya. Orang tua memberikan keteladanan kepada anak-anaknya. Pejabat meneladankan persahabatan dengan lingkungan kepada bawahannya. Begitu juga pengusaha dapat memberikan contoh teladan kepada karyawannya.

3. Ceramah. Metode ini diberikan oleh kyai, ustadz, dosen, guru, pejabat, tokoh dan tetua adat kepada orang banyak dalam suatu forum. Pengajian, acara keluarga (pernikahan, syukuran, sunatan) atau rembug desa dapat dijadikan wahana peduli lingkungan, minimal mengenalkan atau mengingatkan bahwa kita perlu peduli dan menjaga kelestarian fungsi lingkungan.

4. Diskusi. Hal ini dapat dilaksanakan pada setiap pertemuan resmi dan tak resmi, baik di sekolah, kampus, kantor, bahkan pada acara pernikahan, sunatan, dll. Diskusi informal di kalangan keluarga besar atau dengan teman sekantor, sekampus, sedaerah sambil bertukar informasi dapat menjadi "obat mujarab" dalam meluaskan kepedulian masyarakat terhadap fungsi lingkungan.

5. Seminar. Acara seminar biasanya digelar oleh masyarakat kampus atau dinas pemerintah dan pesertanya adalah kalangan yang tingkat pendidikannya relatif tinggi. Acara ini biasanya melibatkan pakar atau nara sumber yang kompeten di bidang lingkungan.

6. Percontohan. Manusia lebih senang melihat sesuatu yang nyata karena dapat segera menilainya, mengapresiasinya. Percontohan, prototipe merupakan bentuk fisik yang dapat dilihat langsung oleh masyarakat. Misalnya, taman, permukiman yang bebas banjir, kantor yang ramah lingkungan karena sudah ber-IPAL, kampus yang nyaman, dll.

7. Spanduk, selebaran, brosur, dan iklan, termasuk yang ditayangkan di media televisi, dirilis di radio, dipasang di jalan-jalan, termasuk di internet seperti milis dan facebook. Ajakan ini sebaiknya menggunakan kalimat efektif agar cepat selesai dibaca dan dapat dimengerti. Kalimatnya pendek-pendek saja, 
boleh sesuai dengan Ejaan Yang Disempurnakan (EYD), boleh juga dengan bahasa gaul anak muda, bergantung pada sasaran yang dituju.

Semoga Pendidikan Lingkungan, baik di pesantren, madrasah, SD, SMP, SMA, SMK, dan lebih khusus di perguruan tinggi di seluruh Indonesia betul-betul berjalan di atas rel idealismenya dan menjadi the avant garde pola pendidikan yang bersahabat dengan lingkungan di Indonesia.*

\section{Daftar Pustaka}

1. Cahyana, Gede. H. (2004), PDAM Bangkrut? Awas Perang Air, Sahara G. Press.

2. Mangunjaya, Konservasi Alam Dalam Islam, Yayasan Obor Indonesia, 2005.

3. Soeriatmadja, Ilmu Lingkungan, Penerbit ITB, 1982.

4. Sumaatmadja, Makna Pendidikan Dalam Membina Kesadaran Lingkungan Hidup, makalah, Institut Teknologi Adityawarman, 1991.

5. Sunardi, Perlindungan Lingkungan, Program Magister Ilmu Lingkungan Universitas Padjadjaran, 2008.

Terbit di Jurnal Sosioteknologi Terapan, Volume XIII, hlm. 176-192.

Bulan Mei 2009, ISBN 978-979-17974-2-9. 